\title{
Epibionts on Flexopecten felipponei (Dall, 1922), an uncommon scallop from Argentina
}

\author{
Laura Schejter and Claudia S. Bremec
}

CONICET and INIDEP, Paseo Victoria Ocampo 1, 7600, Mar del Plata, Argentina, schejter@inidep.edu.ar

\begin{abstract}
Flexopecten felipponei (Dall, 1922) is a non-commercial, seldom reported pectinid from the SW Atlantic Ocean. In this contribution we review its taxonomy, describe epifaunal species and their levels of encrustation, and discuss the composition of the macrobenthic assemblage where this scallop lives. Eighteen epibiont taxa were observed to live on the valves of these scallops. The most frequent and abundant epibionts on F. felipponei were serpulids, barnacles, and oysters. Although both valves were encrusted, the left valves had higher percentages of coverage. The benthic community contained 69 invertebrate taxa that generally characterize other mid-shelf bottoms between $37^{\circ} \mathrm{S}$ and $39^{\circ} \mathrm{S}$. Eight pea crabs of the species Tumidotheres maculatus (Say, 1818) were found inside eight individuals of F. felipponei. Two other scallops had burrows of Polydora websteri Hartman, 1943. These were the first observations of these infestations on F. felipponei.
\end{abstract}

Key words: Epibiosis, Pectinidae, SW Atlantic Ocean

Scallops are distributed worldwide and support important commercial fisheries and mariculture efforts. They are one of the best known groups of bivalves. Numerous studies on the biology, anatomy, physiology, genetics, population dynamics, fishery, and aquaculture of commercial pectinids have been carried out (see Shumway 1991). In Argentina, the commercial pectinids include Aequipecten tehuelchus (d'Orbigny, 1846) and Zygochlamys patagonica (King and Broderip, 1832) (Ciocco et al. in press), target species of a local fishery in the gulfs of northern Patagonia (Lasta et al. 1998, Ciocco et al. 1998) and of a fishery that started in 1996 (Lasta and Bremec 1998), respectively.

During the course of cruises conducted in 2002 to locate new commercial beds of Aequipecten tehuelchus in the coastal shelf waters of Buenos Aires, we observed the presence of the non-commercial pectinid Flexopecten felipponei (Dall, 1922) as part of the benthic community. The species has rarely been recorded from the SW Atlantic Ocean (Waller 1991). It is distributed from $36^{\circ} \mathrm{S}$ to San Matías and Nuevo Gulfs $\left(43^{\circ} \mathrm{S}\right)$, and has been collected in rocky and sandy bottoms from the lower tidal fringe (Castellanos 1970, 1971) and between 40 to $50 \mathrm{~m}$ depth (Ríos 1994, Nuñez Cortés and Narosky 1997). The only biological study on $F$. felipponei indicates that it is a simultaneous hermaphrodite (Penchaszadeh and Giménez 2001).

The availability of a suitable substratum is one of the critical factors for the colonization of sessile species. Molluscs, decapod carapaces, and the spines of sea urchins are frequently used as hard substrata available for attachment of sessile organisms in soft bottoms, together with many other organisms such as ascidians, corals, gorgonians, and sea pens that are also used as surfaces for settlement by invertebrate larvae (Abelló et al. 1990, Davis and White 1994, Gutt and Schickan 1998). Epibiosis is the association between epibionts (organisms growing attached to a living surface) and basibionts (organisms that provide substrate to the epibionts). This association creates a complex network of benefits and disadvantages for both organisms (Wahl 1989). Bivalves are often associated with encrusting epibionts (see Feifarek 1987, Vance 1978, Keough 1984). Epizoic organisms can be very diverse, especially on scallops (i.e., Waloszek 1991, Rosso and Sanfilippo 1994, Fuller et al. 1998, Bremec and Lasta 2002). Studies examining the epibiosis between scallops and other organisms include foraminiferans (Alexander and Delaca 1987), sponges (Evans 1969, Bloom 1975, Forester 1979, Chernoff 1987, Burns and Bingham 2002, Donovan et al. 2002), hydroids (Getchell 1991), polychaetes (Blake and Evans 1973, Bergman et al. 1982, Mori et al. 1985, Ciocco 1990, Sanfilippo 1994), crustaceans (Donovan et al. 2003), bryozoans (Ward and Thorpe 1991), and ascidians (see Uribe et al. 2001 and references therein).

In this contribution we give new information about Flexopecten felipponei from coastal shelf waters of Buenos Aires, Argentina. We review its taxonomy, describe epifaunal species and their levels of encrustation, and discuss the composition of the macrobenthic assemblage where this scallop lives.

\section{MATERIALS AND METHODS}

Sampling was conducted with commercial otter trawls (51 hauls) by the scallopers Atlantic Surf I, Erin Bruce, and $M r$. Big, between 40-50 $\mathrm{m}$ depth and between $39^{\circ} 00^{\prime}$ - 
$39^{\circ} 37^{\prime} \mathrm{S}$ and $60^{\circ} 21^{\prime}-58^{\circ} 47^{\prime} \mathrm{W}$ in February, July, August, and September 2002, and with a dredge by the research vessel Capitán Cánepa (INIDEP) at $38^{\circ} 26^{\prime} \mathrm{S}$ and $57^{\circ} 40^{\prime} \mathrm{W}$ in JanuFl ary 2004 (Fig. 1). Samples of the macrobenthic community were frozen on board. The species of macroinvertebrates comprising this community were identified to the lowest possible level in the laboratory using the available literature (Bernasconi 1964, 1973, Castellanos 1970, Orensanz 1975, Fauchald 1977, Bernasconi and D'Agostino 1977, Boschi et al. 1992, Lana and Bremec 1994, Roux and Bremec 1996, Pérez 1999, and Forcelli 2000). The identification of ascidians was made by Dr. Marcos Tatián.

From a total of 95 specimens of Flexopecten felipponei identified in 26 hauls, we preserved 30 available specimens in $5 \%$ buffered formalin solution in seawater. Presence-absence and quantitative data of epibionts were recorded for right and left valves. A Wilcoxon matched paired test (Steel and Torrie 1985) was used to establish the significance in differences between total abundances of epibionts on each valve. To quantify the level of encrustation, each valve was arbi-

F2 trarily divided into seven regions (Fig. 2), roughly following the procedures of Ward and Thorpe (1991) and Sanfilippo (1994). The percentage of coverage of each species of epibiont was estimated by eye as either $<10 \%, 10-30 \%$, or $>30 \%$ of the surface for each region of each valve. Maximum shell width was measured to the nearest $\mathrm{mm}$ with calipers (Fig. 2).

\section{RESULTS}

\section{Taxonomy}

Our study material agreed well with the original description of Flexopecten felipponei (Dall, 1922). The genus belongs to the Decatopecten group (Waller 1991) and is characterized by plain shells with 5-8 ribs that are sometimes

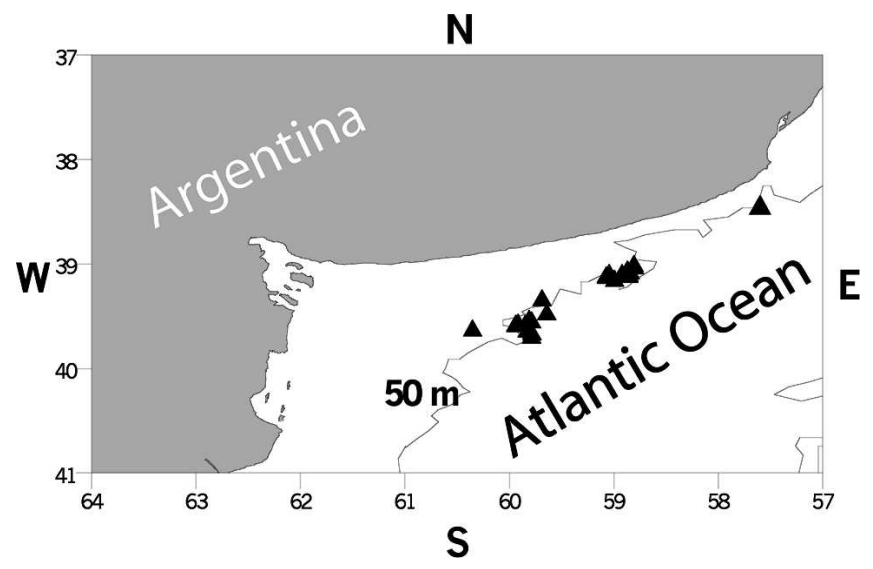

Figure 1. Map of the sampling area. Triangles mark sampling sites.

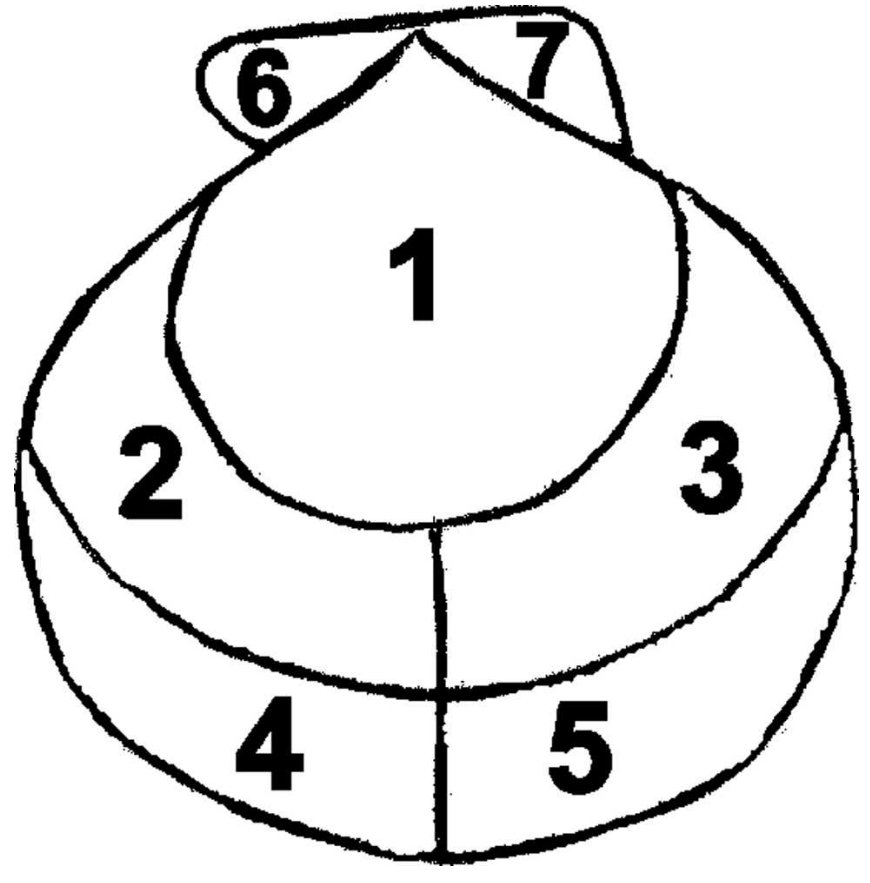

Figure 2. Diagram showing division of each valve into 7 arbitrary regions and the measurement of maximum shell width.

inconspicuous. Flexopecten felipponei is an uncommon species from the Argentine Sea. It has been synonymized as:

Flexopecten felipponei (Dall, 1922)

Pecten felipponei: Dall 1922; Carcelles 1944

Chlamys felipponei: Castellanos 1970,1971; Waloszek 1984; Rombouts 1991; Ríos 1994; Nuñez Cortés and Narosky 1997; Forcelli 2000

Aequipecten felipponei: Nuñez Cortés and Narosky 1997; Penchaszadeh and Giménez 2001

Flexopecten felipponei: Waller 1991; Peña 2001

We follow the nomenclature proposed by Waller (1991), who assigns the species to the genus Flexopecten based on the external morphology of the shell.

\section{Epibiosis}

Epibionts were present on both valves of all studied individuals of Flexopecten felipponei. Tube-building polychaetes, barnacles, and oysters were the most frequent epizoic organisms on both valves (Fig. 3). Significant differ- [3 ences were found in total number of epibionts recorded between both valves $(Z=3.3629, \mathrm{p}<0.001)$; the highest number of organisms was always found on the upper (left) valve.

Serpulid tubes were present on $90 \%$ of the sampled scallops and were found on both valves (Fig. 4). These tubes F4 were found in all 7 regions on both valves, with variable 


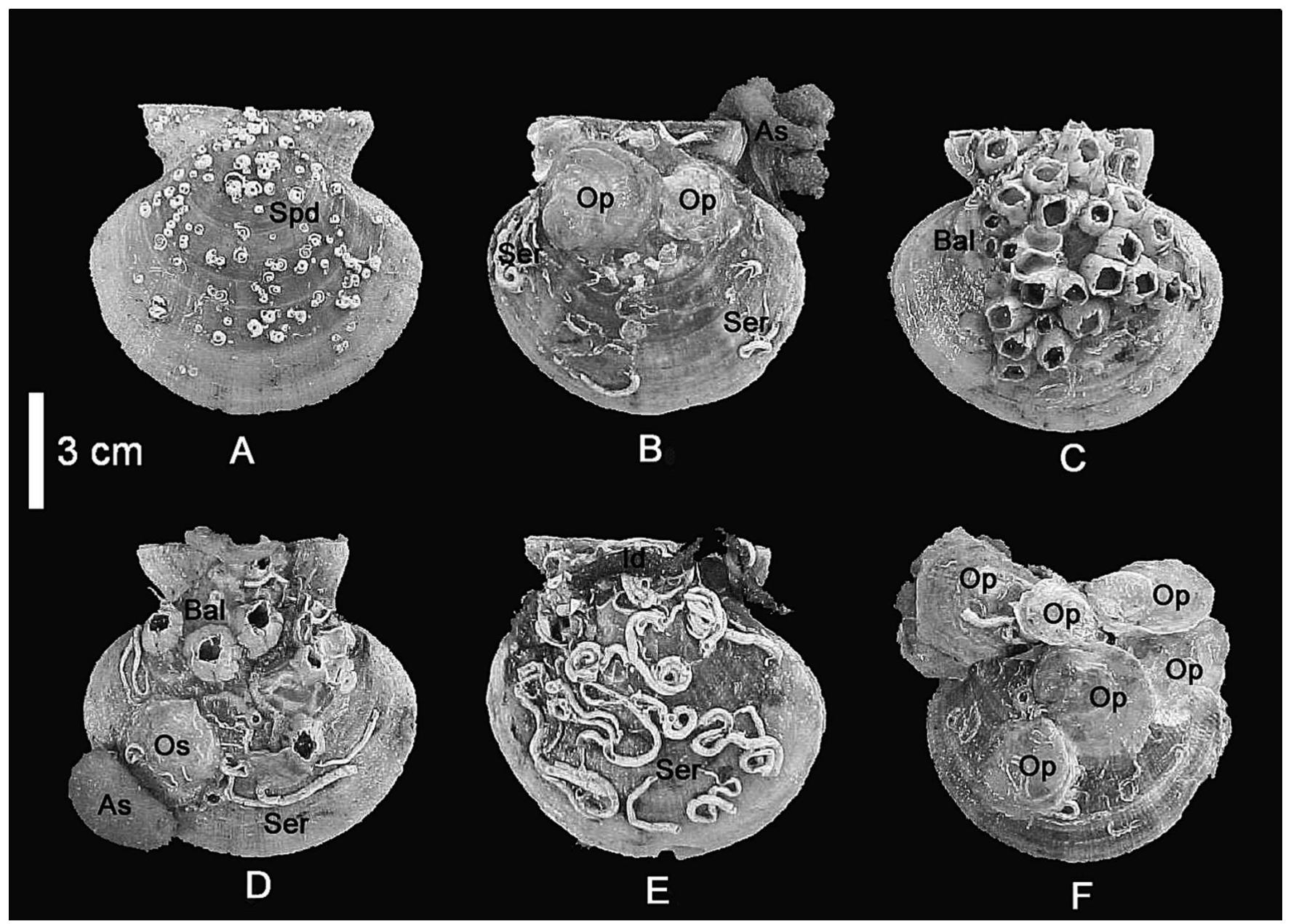

Figure 3. Epizoic organisms on Flexopecten felipponei from the coastal shelf waters of Buenos Aires. A, Spirorbid polychaetes. B, Several individuals of Ostrea puelchana d'Orbigny, 1841, ascidians, and some serpulid tubes. C, Balanus cf. amphitrite. D, Balanus cf. amphitrite, ascidians, serpulid tubes, and individuals of Ostrea puelchana. E, Idanthyrsus armatus Kinberg, 1867 (Sabellariidae) and serpulid tubes. F, Ostrea puelchana, some with serpulid tubes on them. Abbreviations: As, ascidian; Bal, Balanus cf. amphitrite; Ia, Idanthyrsus armatus; Op, Ostrea puelchana; Ser, Serpulid polychaetes; Spd, Spirorbid polychaetes.

F5 percentages of covered surface in each region (Fig. 5A-B). In some cases the complete valve was covered, while in others only a few tubes were found (Fig. 3). The number of tubes found on a single valve varied between 1 and 65. Serpulids were also epibionts of other epibionts of Flexopecten felipponei. For example, they also occurred on epizoic individuals of Ostrea puelchana d'Orbigny, 1842 (Fig. 3D-F). Only 3 small individuals ( $<26 \mathrm{~mm}$ maximum height) of $F$. felipponei had valves that lacked serpulid tubes. Tubes of the polychaete Phyllochaetopterus sp. were found on both valves (left: 60\%; right: 46.7\%) (Fig. 4). These tubes were small and consequently covered small surfaces $(<10 \%)$. They were found on both valves, more abundantly on the left (2-16 tubes) than on the right (1-5 tubes). Tubes of Idanthyrsus armatus Kinberg, 1867 were found only on left valves in
$33.3 \%$ of the sampled scallops (Fig. 4). These tubes were found on the left valves in any of the 7 regions, but there was generally only one tube per valve. In some cases, the open region of the tube extended over the valve (Fig. 3E). Spirorbid tubes were very abundant on $3(10 \%)$ scallops belonging to a particular sample (Fig. 4). In any case, they were not frequent epibionts on F. felipponei; only 3 scallops had between 47 and 224 tubes per valve, which were homogeneously distributed on both valves (Fig. 3A). Members of the Eunicidae (Eunice magellanica Mc Intosh, 1885 and Eunice argentinensis [Treadwell, 1929]) were recorded on only a few scallops (Fig. 4). A few burrows of the parasitic polychaete Polydora websteri Hartman, 1943 were found on 2 left (upper) valves $(6.67 \%)$.

Barnacles (Balanus cf. amphitrite) were found on 26 


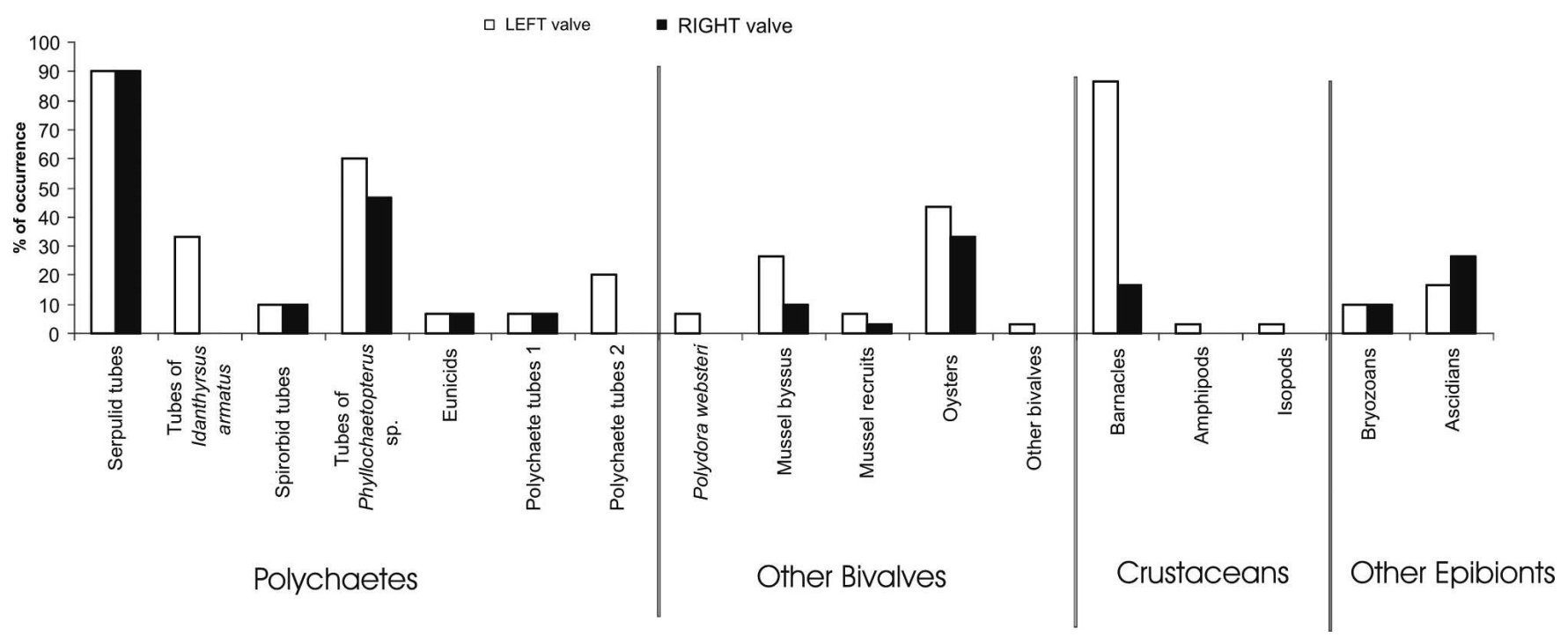

Figure 4. Frequency of occurrence of epibionts on Flexopecten felipponei (based on presence-absence data, $\mathrm{N}=30$ ).

$(86.7 \%)$ left valves, but only on $5(16.7 \%)$ of the right ones (Fig. 4). They were found most frequently on the left (upper) valves, with high values of coverage especially at regions 1,2 , 3, and 6 (Fig. 5C-D). The left valves had between 1 and 36 individual barnacles, and the right valves between 1 and 4 individuals. Region 1 of the valve was conspicuously preferred as a settlement surface; in some cases it was completely covered by barnacles (Fig. 3C).

Oysters (Ostrea puelchana) were found on $43.3 \%$ and $33.3 \%$ of the left and right valves, respectively (Fig. 4). They were found on both valves and in all regions (Fig. 5E-F). In many cases, the oysters completely covered the auricular areas or extended over the edges of the scallops (Fig. 3F). Numbers of epizoic oysters varied between 1 and 9. Serpulids and individuals of Phyllochaetopterus sp. also encrusted epizoic oysters (Fig. 3B, D, F). Recruits of the mussel Mytilus edulis d'Orbigny, 1846 and other unidentified small bivalves were recorded as epibionts on a few scallops (Fig. 4).

Solitary ascidians were found on $16.7 \%$ and $26.7 \%$ of the left and right scallop valves, respectively (Fig. 4). These organisms were observed in low numbers (1-2), on both valves, and in all regions (i.e., Fig. 3B-D). Epizoic organisms such as bryozoan colonies, small isopods, and amphipods were also observed on a few scallops (Fig. 4). The crustaceans were free-living between the crevices in the association of epibionts.

There were no shells without epibionts; even small individuals had epizoic organisms on their valves.

\section{Macrobenthic assemblage}

Individuals of Flexopecten felipponei (between 16 and 90 $\mathrm{mm}$ maximum shell width) were primarily found associated with the tehuelche scallop Aequipecten tehuelchus, as part of the by-catch of the fishery. Other organisms of commercial importance found in the benthic community were the common mussel Mytilus edulis, the oyster Ostrea puelchana, and the mussel Atrina seminuda (d'Orbigny, 1846). A total of 69 invertebrate taxa were recorded from the study area (Table 1). T1

\section{Infestation}

Seven females (between 6.6 and $9.6 \mathrm{~mm}$ carapace length) and one male (3.8 mm carapace length) of the pea crab Tumidotheres maculatus (Say, 1818) were found inside eight different specimens of Flexopecten felipponei. Two left scallop valves were burrowed into by the parasitic polychaete Polydora websteri.

\section{DISCUSSION}

We found 18 epizoic taxa on the valves of Flexopecten felipponei from the sublittoral of Buenos Aires. The most frequent and abundant epibionts on Flexopecten felipponei were serpulids, barnacles, and oysters. Additional organisms such as the gastropods Calliostoma sp., Crepidula spp. and Calyptraea sp. occured as part of the fauna closely related with the epibiont association. Previously, only the presence of bryozoans and polychaetes on five specimens of this scallop was mentioned by Castellanos (1971).

The number of associated species greatly varies in different species of scallops recorded from different habitats. Eleven species were found on cultured Euvola ziczac (Linnaeus, 1758) and Nodipecten nodosus (Linnaeus, 1758) in Cariaco Gulf, Venezuela, but in Santa Catarina, Brazil, 16 

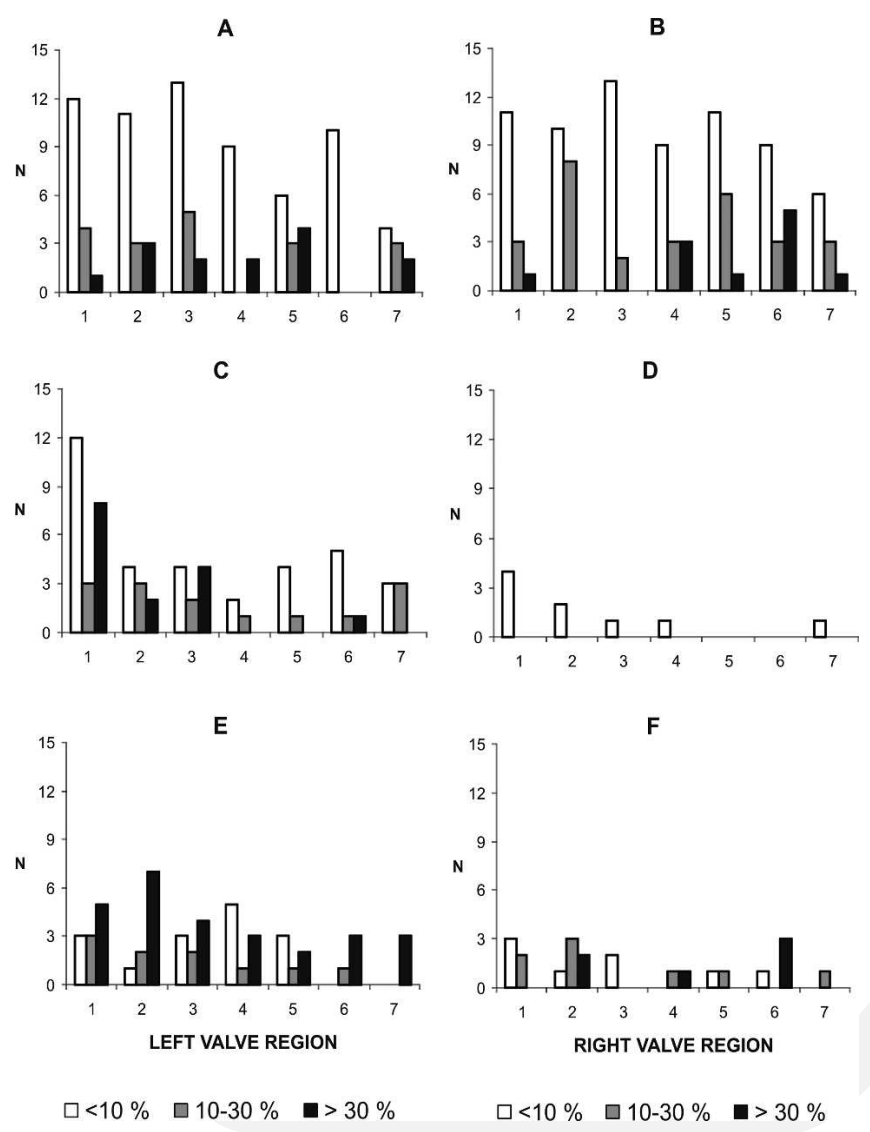

Figure 5. Portion of the surface (\%) of each region of each valve of Flexopecten felipponei covered by: A-B, serpulids; C-D, barnacles; E-F, oysters.

species were found on N. nodosus. In Magdalena Bay and Bahía de la Paz, Mexico, 36 species were found inside or outside the valves of Argopecten ventricosus (Sowerby II, 1842) and Nodipecten subnodosus (Sowerby, 1835). In Tongoy, Guanaqueros, and Inglesa Bays, Chile, a total of 63 species were recorded associated with the valves of Argopecten purpuratus (Lamarck, 1819) (Uribe et al. 2001). Forty nine epizoic taxa were associated with the non-cultured species Placopecten magellanicus (Gmelin, 1791) in the Bay of Fundy, Canada (Fuller et al. 1998) and 19 sessile epizoic species were recorded on Zygochlamys patagonica in commercial beds of Argentina (Bremec and Lasta 2002, Bremec et al. 2003).

Although both valves were encrusted, the left (upper) valves had higher percentages of coverage. Except for ascidians, the epibiont species were more abundant on the left valve and occured on all regions. Flexopecten felipponei is a non-sedentary species that should have limited swimming capacity (Stanley 1970), which would permit it to escape from predators, as observed in other scallops (see Wilkens
1991). Epibionts can settle on both valves, depending on the living position adopted by the scallop, which seems to be more frequently with the right valve in contact with the substrate.

Surprisingly, no sponges were found on our specimens of Flexopecten felipponei. The symbiotic relationship between scallops and sponges has been studied worldwide (Bloom 1975, Forester 1979, Chernoff 1987, Burns and Bingham 2002, Donovan et al. 2002). Cover by sponges is believed to protect pectinids by camouflaging the shell and to reduce predation by asteroids by altering the surface texture of shells. Although we found sponges in the study area, they were encrusting other invertebrates, mainly crustaceans and eunicid tubes.

The majority of the epibionts on Flexopecten felipponei were sessile suspension-feeders. They created additional surfaces and crevices where other small free-living individuals, such as isopods and amphipods, could live. We found only a small number of free-living organisms inhabiting the epizoic association. However, we consider that the number of vagile species associated with this scallop is higher and underestimated due to the limitations of our sampling procedure.

Many of the macroinvertebrates that were part of the benthic assemblage associated with Flexopecten felipponei were also recorded from other middle shelf bottoms between $37^{\circ} \mathrm{S}$ and $39^{\circ} \mathrm{S}$ where the mussel Mytilus edulis was dominant. The coastal area of Buenos Aires is highly heterogeneous, with patches of different types of substrates, and the most diversified benthic assemblages are usually dominated by bivalves (Bremec and Roux 1997, Schejter and Bremec 2003). The settlement substrate and microhabitats provided by bivalves and associated epibionts greatly influence community structure by increasing the species richness of the benthic assemblages. In our study area, where the soft bottoms are subjected to hydrodynamic conditions that remove sediments, the scallops provided substrate for the settlement of encrusting filter feeders and permitted the colonization of coastal environments.

This is the first record of Flexopecten felipponei as a host of the spionid polychaete Polydora websteri and the pea crab Tumidotheres maculatus. Species of the genus Polydora are reported to be a pest of bivalves (Getchell 1991). They have been found in many commercial species such as Placopecten magellanicus (Bergman et al. 1982), Argopecten purpuratus (Basilio et al. 1995), Patinopecten yessoensis (Jay, 1857) (Mori et al. 1985), Pecten maximus (Linnaeus, 1758) (Mortensen et al. 2000), and Aequipecten tehuelchus (Ciocco 1990). Pea crabs cause slight irritation to severe structural alterations and pathology in their scallop hosts (Kruckzynski 1972, Getchell 1991, Bologna and Heck 2000, Narvarte and Saiz 2004). Tumidotheres maculatus was also reported inside sev- 
Table 1. Invertebrates recorded from the study area.

\section{PORIFERA}

Porifera unidentified

CNIDARIA

Tripalea clavaria (Studer, 1878)

Actinaria unidentified

Hydrozoa

ANNELIDA

Aphroditidae

Eunice magellanica McIntosh, 1885

Chaetopterus variopedatus (Ranier, 1807)

Phyllochaetopterus sp.

Idanthyrsus armatus Kinberg, 1867

Polydora websteri Hartman, 1943

Spirorbidae

Serpulidae

Maldanidae

Polychaeta unidentified

\section{MOLLUSCA}

Aequipecten tehuelchus (d'Orbigny, 1846)

Flexopecten felipponei (Dall, 1922)

Ostrea puelchana d'Orbigny, 1841

Pododesmus rudis (Broderip, 1834)

Mytilus edulis d'Orbigny, 1846

Atrina seminuda (d'Orbigny, 1846)

Panopea abreviata (Valenciennes, 1839)

Pitar rostrata (Koch, 1844)

Bivalve unidentified

Calyptraea sp.

Crepidula spp.

Calliostoma sp.

Zidonia dufresnei (Donovan, 1823)

Fissurellidea megatrema d'Orbigny, 1841

Nudibranchia

Octopus tehuelchus d'Orbigny, 1834

ARTHROPODA

Peltarion spinosulum (White, 1843)

Platyxanthus patagonicus A. Milne Edwards, 1879

Coenophthalmus tridentatus A. Milne Edwards, 1879

Rochinia gracilipes A. Milne Edwards, 1875

Collodes rostratus A. Milne Edward, 1878

Pilumnoides hassleri A. Milne Edward, 1880

Leurocyclus tuberculosus (H. Milne Edwards and Lucas, 1843)

Libinia spinosa $\mathrm{H}$. Milne Edwards, 1834

Pelia rotunda A. Milne Edwards, 1875

Leucipa pentagona H. Milne Edwards, 1833

Propagurus gaudichaudi (H. Milne Edwards, 1836)

Pagurus sp.

Pinnotheridae

Tumidotheres maculatus (Say, 1818)

Pinnixa brevipollex Rathbun, 1896

Balancus cf. amphitrite

Lepadomorpha

Amphipoda unidentified

Isopoda unidentified
Table 1. (Continued)

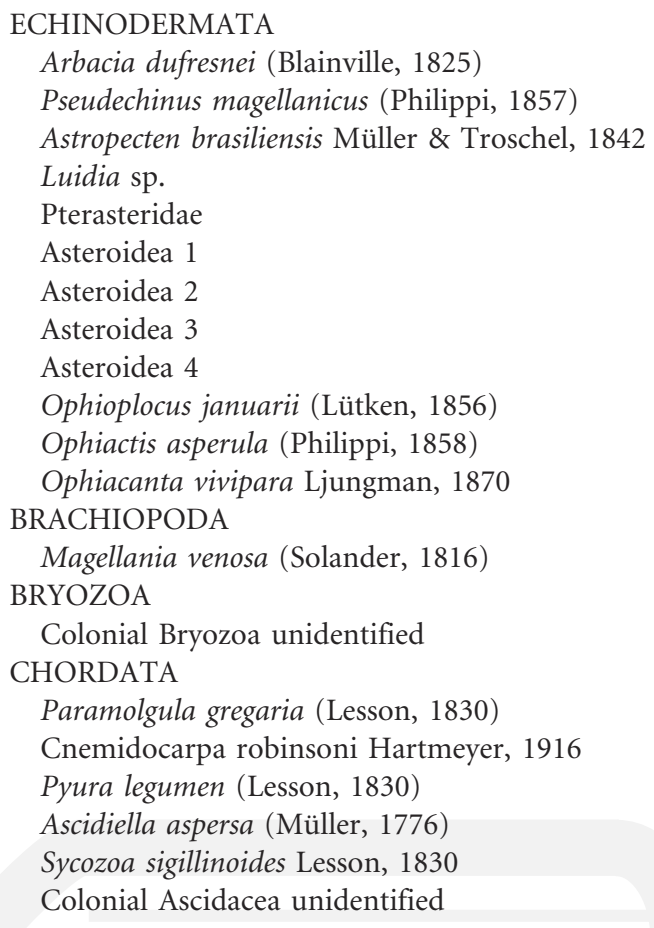

eral mollusks, in the tunicate Molgula sp., inside tubes of the polychaete Chaetopterus variopedatus (Renier, 1804), and on the asteroid Asterias vulgaris Verril, 1866 (Fenucci 1975).

\section{ACKNOWLEDGMENTS}

We are grateful to Angel Marecos and Mónica Di Pace for valuable help in the sampling work, to Dr. Enrique Boschi for helping in the identification of the pea crab, to Dr. Marcos Tatian for the identification of the ascidians, to Diego Zelaya for helping with the bibliography, and to Daniel Hernandez for statistical supervision. The manuscript greatly benefited from comments and suggestions by Dr. Sandra Shumway, Dr. Janice Voltzow, and an anonymous reviewer. This paper was funded by PEI 6026, PICT 0115080 and Antorchas 13900-13. This is INIDEP Contribution $\mathrm{N}^{\circ} 1356$.

\section{LITERATURE CITED}

Abelló, P., R. Villanueva, and J. M. Gili. 1990. Epibiosis in deep-sea crab populations as indicator of biological and behavioural characteristics of the host. Journal of the Marine Biological Association of the United Kingdom 70: 687-695.

Alexander, S. P. and T. E. Delaca. 1987. Feeding adaptations of the 
foraminiferan Cibides refulgens living epizoically and parasitically on the Antarctic scallop Adamussium colbecky. Biological Bulletin 173: 136-159.

Basilio, C., J. I. Cañete, and N. Rozbaczylo 1995. Polydora sp. (Spionidae), un poliqueto perforador de las valvas del ostión Argopecten purpuratus (Bivalvia: Pectinidae) en Bahía Tongoy, Chile. Revista de Biología Marina de Valparaíso 30: 71-77.

Bergman, K. M, R. W. Elner, and M. J. Risk. 1982. The influence of Polydora websteri borings on the strength of the shell of the sea scallop, Placopecten magellanicus. Canadian Journal of Zoology 60: 2551-2556.

Bernasconi, I. 1964. Asteroideos argentinos. Claves para los órdenes, familias, subfamilias, y géneros. Physis 24: 241-277.

Bernasconi, I. 1973. Los equinodermos colectados por el "Walter Herwig” en el Atlántico Sudoeste. Hidrobiología 3: 287-334.

Bernasconi, I. and M. M. D’Agostino. 1977. Ofiuroideos del mar epicontinental Argentino. Revista del Museo Argentino de Ciencias Naturales "Bernardino Rivadavia" e Instituto Nacional de Investigaciones de las Ciencias Naturales. Hidrobiología 5: $65-114$.

Blake, J. A. and J. W. Evans. 1973. Polydora and related genera as borers in mollusk shells and other calcareous substrates (Polychaeta: Spionidae). Veliger 15: 235-249.

Bloom, S. A. 1975. The motile escape response of a sessile prey: A sponge-scallop mutualism. Journal of Experimental Marine Biology and Ecology 17: 311-321.

Bologna, P. A. and K. L. Heck, Jr. 2000. Relationship between pea crab (Pinnotheres maculatus) parasitism and gonad mass of the bay scallop (Argopecten irradians). Gulf and Caribbean Research 12: 43-46.

Boschi, E. E., K. Fischbach, and M. I. Lorio. 1992. Catálogo ilustrado de los crustáceos estomatópodos y decápodos marinos de Argentina. Frente Marítimo 10: 1-94.

Bremec, C. S. and M. L. Lasta. 2002. Epibenthic assemblage associated with scallop (Zygochlamys patagonica) beds in the Argentine shelf. Bulletin of Marine Science 70: 89-105.

Bremec, C. and A. Roux. 1997. Resultados del análisis de una campaña de investigación pesquera sobre comunidades bentónicas asociadas a bancos de mejillón (Mytilus edulis platensis D’Orb.) en costas de Buenos Aires, Argentina. Revista de Investigación y Desarrollo Pesquero 11: 153-166.

Bremec, C., A. Marecos, L. Schejter, and M. Lasta. 2003. Guía Técnica para la Identificación de Invertebrados Epibentónicos Asociados a los Bancos de Vieira Patagónica (Zygochlamys patagonica) en el Mar Argentino. Publicaciones Especiales INIDEP. Mar del Plata.

Burns, D. O. and B. L. Bingham. 2002. Epibiotic sponges on the scallops Chlamys hastata and Chlamys rubida: Increased survival in a high-sediment environment. Journal of the Marine Biological Association of the United Kingdom 82: 961-966.

Carcelles, A. 1944. Catálogo de los moluscos marinos de Puerto Quequén. Revista del Museo de La Plata (nueva serie), Zoología 23: 233-309.

Castellanos, Z. A. J. 1970. Catálogo de los moluscos marinos bonaerenses. Anales de la Comisión de Investigaciones Científicas de Buenos Aires 8: 1-365.
Castellanos, Z. A. J. 1971. Los Chlamys más comunes del Mar Argentino. Neotrópica 17: 55-66.

Chernoff, H. 1987. Factors affecting mortality of the scallop Chlamys asperrima (Lamarck) and its epizoic sponges in South Australian waters. Journal of Experimental Marine Biology and Ecology 109: 155-172.

Ciocco, N. F. 1990. Infestación de la vieyra tehuelche (Chlamys tehuelcha (d'Orbigny)) por Polydora websteri Hartman (Polychaeta: Spionidae) en el golfo San José (Chubut: Argentina): Un enfoque cuantitativo. Biología Pesquera 19: 9-18.

Ciocco, N. F., M. L. Lasta, and C. S. Bremec. 1998. Pesquerías de bivalvos: Mejillón, vieiras (tehuelche y patagónica) y otras especies. El Mar Argentino y sus Recursos Pesqueros 2: 143-166.

Ciocco, N., M. L. Lasta, M. Narvarte, C. Bremec, E. Bogazzi, J. Valero, and J. M. Orensanz. In press. Argentina. In: S. E. Shumway, ed., Scallops: Biology, Ecology and Aquaculture, $2^{\text {nd }}$ Edition. Elsevier, Amsterdam.

Dall, W. H. 1922. Two new bivalves from Argentina. The Nautilus 36: $58-59$.

Davis, A. R. and G. A. White. 1994. Epibiosis in a guild of sessile subtidal invertebrates in south-eastern Australia: A quantitative survey. Journal of Experimental Marine Biology and Ecology 177: 1-14.

Donovan, D. A., B. L. Bingham, H. M. Farren, R. Gallardo, and V. L. Vigilant. 2002. Effects of sponge encrustation on the swimming behaviour, energetics and morphometry of the scallop Chlamys hastata. Journal of the Marine Biological Association of the United Kingdom 82: 469-476.

Donovan, D. A., B. L. Bingham, M. From, A. F. Fleisch, and E. S. Loomis. 2003. Effects of barnacle encrustation on the swimming behaviour, energetics, morphometry, and drag coefficient of the scallop Chlamys hastata. Journal of the Marine Biological Association of the United Kingdom 83: 813-819.

Evans, J. W. 1969. Borers in the shell of the sea scallop, Placopecten magellanicus. American Zoologist 9: 775-782.

Fauchald, K. 1977. The polychaete worms: Definitions and key to the orders, families and genera. Natural History Museum of Los Angeles County Science Series 28: 1-190.

Feifarek, B. P. 1987. Spines and epibionts as antipredator defenses in the thorny oyster Spondylus americanus Hermann. Journal of Experimental Marine Biology and Ecology 105: 39-56.

Fenucci J. L. 1975. Los cangrejos de la familia Pinnotheridae del litoral argentino (Crustacea, Decapoda, Brachyura). Physis (A)34: 165-184.

Forcelli, D. O. 2000. Moluscos Magallánicos. Guía de Moluscos de Patagonia y Sur de Chile, Vol. 2. Vázques Mazzini, Buenos Aires.

Forester, A. J. 1979. The association between the sponge Halichondria panicea (Pallas) and scallop Chlamys varia (L. ): A commensal protective mutualism. Journal of Experimental Marine Biology and Ecology 36: 1-10.

Fuller, S., E. Kenchington, D. Davis, and M. Butler. 1998. Associated Fauna of Commercial Scallop Grounds in the Lower Bay of Fundy. Marine Issues Committee, Special Publication 2. Ecology Action Centre, Halifax.

Getchell, R. G. 1991. Diseases and parasites of scallops. In: S. E. 
Shumway, ed., Scallops: Biology, Ecology and Aquaculture, Elsevier, Amsterdam. Pp. 471-494.

Gutt, G. and T. Schickan. 1998. Epibiotic relationships in the Antarctic benthos. Antarctic Science 10: 398-405.

Keough, M. J. 1984. Dynamics of the epifauna of the bivalve Pinna bicolor: Interactions among recruitment, predation and competition. Ecology 65: 677-688.

Kruczynski, W. L. 1972. The effect of the pea crab, Pinnotheres maculatus Say, on the growth of the bay scallop, Argopecten irradians concentricus Say. Chesapeake Science 13: 218-220.

Lana, P. C. and C. S. Bremec. 1994. Sabellariidae (Annelida: Polychaeta) from South America. In: J. C. Dauvin, L. Laubier, and D. J. Reish, eds., Actes de la $4^{\text {ème }}$ Conférence Internationale des Polychètes. Mémoires du Muséum National d'Histoire Naturelle 162: 211-222.

Lasta, M. L. and C. Bremec. 1998. Zygochlamys patagonica in the Argentine Sea: A new scallop fishery. Journal of Shellfish Research 17: 103-111.

Lasta, M. L., N. F. Ciocco, C. S. Bremec, and A. M. Roux. 1998. Moluscos bivalvos y gasterópodos. El Mar Argentino y sus Recursos Pesqueros 2: 115-142.

Mori, K., W. Sato, T. Nomura, and M. Imajima. 1985. Infestation of the Japanese scallop Patinopecten yessoensis by boring polychaetes, Polydora, on the Okhotsk Sea coast of Hokkaido, especially in Abashiri waters. Bulletin of the Japanese Society of Science and Fisheries 51: 371-380.

Mortensen, S., T. Van der Meeren, A. Fosshage, I. Hernar, L. Hakestad, L. Torkildsen, and O. Bergh. 2000. Mortality of scallop spat cultivation, infested with tube dwelling bristle worms, Polydora sp. Aquaculture International 8: 267-271.

Narvarte, M. A. and M. N. Saiz. 2004. Effects of the pinnotherid crab Tumidotheres maculatus on the tehuelche scallop Aequipecten tehuelchus in the San Matías Gulf, Argentina. Fisheries Research 67: 207-214.

Nuñez Cortés, C. and T. Narosky. 1997. Cien caracoles argentinos. Albatros, Buenos Aires.

Orensanz, J. M. 1975. Los anélidos poliquetos de la Provincia Biogeográfica Argentina. VII. Eunicidae y Lysaretidae. Physis 34: 85-111.

Peña, J. B. 2001. Taxonomía, morfología, distribución, y hábitat de los pectínidos Iberoamericanos. In: A. N. Maeda-Martinez, ed., Los Moluscos Pectínidos de Iberoamérica: Ciencia y Acuicultura. McGraw-Hill, México. Pp. 1-25.

Penchaszadeh, P. E. and J. Giménez. 2001. Sexuality in three South American Atlantic species of the genus Aequipecten. In: J. E. Illanes, ed., Book of Abstracts of the $13^{\text {th }}$ International Pectinid Workshop. Universidad Católica del Norte, Coquimbo, Chile. Pp. 135-136.

Pérez, C. D. 1999. Taxonomía, Distribución y Diversidad de los Pennatulacea, Gorgonacea y Alcyonacea del Mar Epicontinental Argentino y Zonas de Influencia. Ph.D. Dissertation, Universidad Nacional de Mar del Plata, Argentina.

Ríos, E. 1994. Seashells of Brazil. Fundación de la Universidad de Río Grande do Sul, Río Grande, Brazil.

Rombouts, A. 1991. Guidebook to Pecten Shells. Recent Pectinidae and Propeamussiidae of the World. W. Backhuys, Universal Book Services, Oegstgeest, Netherlands.

Rosso, A. and R. Sanfilippo. 1994. Epibionts distribution pattern of Chlamys patagonica (King and Broderip) of the Magellan Strait. Memorie di Biologia Marina e di Oceanografia 19: 237240.

Roux, A. and C. Bremec. 1996. Brachiopoda collected in the western South Atlantic by R/V Shinkai Maru Cruises (1978-1979). Revista de Investigación y Desarrollo Pesquero 10: 109-114.

Sanfilippo, R. 1994. Polychaete distribution patterns on Chlamys patagonica of the Magellan Strait. In: J. C. Dauvin, I. Laubier, and D. J Reish, eds., Actes de la $4^{\text {ème }}$ Conférence Internationale des Polychètes. Mémoires du Muséum National d'Histoire Naturelle 162: 535-540.

Schejter, L. and C. Bremec. 2003. Fauna bentónica de plataforma media bonaerense: Prospección de especies de interés comercial. In: E. E. Boschi, ed., Libro de Resúmenes de las V Jornadas Nacionales de Ciencias del Mar. Universidad Nacional de Mar del Plata, Mar del Plata, Argentina. P. 169.

Shumway S. E., ed. 1991. Scallops: Biology, Ecology and Aquaculture. Elsevier, Amsterdam.

Stanley, S. M. 1970. Relation of shell form to life habits in the Bivalvia (Mollusca). Memoirs of the Geological Society of America 125: 1-296.

Steel, R. G. D. and J. H. Torrie. 1985. Bioestadística: Principios y procedimientos, $2^{\text {nd }}$ Ed. McGraw-Hill, Bogotá.

Uribe, E., C. Lodeiros, E. Félix-Pico, and I. Etchepare. 2001. Epibiontes en pectínidos de Iberoamérica. In: A. N. MaedaMartínez, ed., Los Moluscos Pectínidos de Iberoamérica: Ciencia y Acuicultura. McGraw-Hill, México. Pp. 249-266.

Vance, R. R. 1978. A mutualistic interaction between a sessile marine clam and its epibionts. Ecology 59: 679-685.

Wahl, M. 1989. Marine epibiosis. I. Fouling and antifouling: Some basic aspects. Marine Ecology Progress Series 58: 175-189.

Waller, T. R. 1991. Evolutionary relationships among commercial scallops (Mollusca: Bivalvia: Pectinidae). In: S. E. Shumway, ed., Scallops: Biology, Ecology and Aquaculture. Elsevier, Amsterdam. Pp. 1-73.

Walossek, D. 1991. Chlamys patagonica (King and Broderip, 1832), a long "neglected" species from the shelf off the Patagonia coast. In: S. E. Shumway and P. A. Sandifer, eds., World Aquaculture Workshops I. An International Compendium of Scallop Biology and Culture. The World Aquaculture Society, Baton Rouge. Pp. 256-263.

Waloszek, D. 1984. Variabilität, taxonomie und Verbreitung von Chlamys patagonica (King and Broderip, 1832) und Anmerkungen zu weiteren Chlamys-Arten von der Südspitze Süd-Amerikas (Mollusca, Bivalvia, Pectinidae). Verhandlungen des naturwissenschaftlichen Vereins Hamburg 27: 207-276.

Ward, M. A. and J. P. Thorpe. 1991. Distribution of encrusting bryozoans and other epifauna on the subtidal bivalve Chlamys opercularis. Marine Biology 110: 253-259.

Wilkens, L. A. 1991. Neurobiology and behaviour of the scallop. In: S. E. Shumway, ed., Scallops: Biology, Ecology and Aquaculture, Elsevier, Amsterdam. Pp. 429-470.

Accepted: 3 February 2006 